\title{
Информатика
}

\author{
УДК [050+070]:001:004.738.5
}

ББК 76.02

DOI 10.20913/1815-3186-2016-4-19-23

\section{A SCIENTIFIC JOURNAL WEBSITE IN ONLINE SCIENTIFIC COMMUNICATIONS}

\author{
(C) L. B. Shevchenko, 2016 \\ State Public Scientific Technological Library of the Siberian Branch of the Russian Academy of Sciences, \\ Novosibirsk, Russia; e-mail: obzor@spsl.nsc.ru
}

\begin{abstract}
The results of the study of scientific journals websites on various subjects are introduced. It was analyzed what data are presented on websites, what services and for what user groups are oriented. It is concluded that scientific journal web-sites are constantly evolving, giving new resources and services to all interested groups of users in terms of the communicative approach, is an important element in the online environment of scientific communication. Sites of domestic journals on the library subjects, unfortunately, lag behind foreign ones. The research results will be used for further development of «Bibliosphere» journal website.
\end{abstract}

Keywords: website, scientific journals, scientific communication, online environment, library journals.

Citation: Shevchenko L. B. A scientific journal website in online scientific communications // Bibliosphere. 2016. № 4. P. 19-23. DOI: 10.20913/1815-3186-2016-4-19-23.

$\mathrm{D}$ evelopment of scientific communication system, the acceleration of information exchange has shown that at present a scientific journal, as a main ways of scientific communication, can't exists without a website.

To work effectively for promoting a journal in online environment, a website must meet certain requirements, which impose major organizations engaged in creating and processing scientific journals [9]. These requirements relate to the site content, as well as the availability of certain resources and services.

The site is believed to be visited if it contains information of interest for users having particular purposes and provides high quality services. High impact factor of a journal can draw attention to a journal web-site. However, many other factors affect the visibility of a journal and its webometric rank: site structure, speed and facility in finding information $[3,6,8]$.

In 2002 and 2007 the study of scientific journals websites on different subjects was carried on in order to find out what information was available on them, for whom it was intended $[11,12]$. The results have shown that journal sites are developing dynamically, adding a number of sections intended for all categories of users. The core sections necessary for a journal publishing house website were found:

- General information about the journal: subject, location, editorial board,

- Information about the publishing organization,

- Archive: content,

- Instructions for authors,

- Subscription,

- Full texts,

- Article abstracts,

- Announcement, current release, accepted to publication,
- Thematic and authors indices,

- Information on the journal subject (methodological, law documents, new literature, other information),

- News,

- Internet links.

In our view, this list of sections serves as a model of journal sites, based on which publishing houses develop their websites. The study results were used to create and maintain the website of the journal «Bibliosphere» (http:// www.spsl.nsc.ru/professionalam/bibliosfera/).

For further development of «Bibliosphere» website it was necessary to study the experience of the advanced sites of journals, analyze the dynamics of their development. In 2016 the research was continued. 20 sites of international scientific journals on various subjects and sites of 20 foreign journals on library topics were reviewed.

The selection of journals to research was carried on with SCImago Journal Ranking (SJR) developed by SCImago research team. SJR provides an opportunity to evaluate the scientific prestige of publications based on the number of citations for each weighty document. Websites of journals with the highest values of SJR on the basis of Scopus data were analyzed, as well as sites of 11 leading Russian library journals. Selection of journals was made by rating of SCIENCE INDEX for 2014. 2 of 11 websites were unavailable.

The analysis was performed on the following parameters: presence or absence of general information about publications, publishing organization, information for different groups of users, metadata, full texts of publications, presence or absence of additional services, for whom the information is intended, what user groups information is oriented. The results are shown in the table.

Comparing the study results of 2007 and 2016, we can conclude that the sections on the websites has significantly expanded and changed. As before, most of the 
The information structure on websites of journal publishers

\begin{tabular}{|c|c|c|c|c|c|c|c|}
\hline \multirow{3}{*}{ Information } & \multicolumn{3}{|c|}{ Available on journal websites: (number of sites) } & \multirow{2}{*}{\multicolumn{4}{|c|}{$\begin{array}{c}\text { Intended for: } \\
(+- \text { intended, }-- \text { not intended })\end{array}$}} \\
\hline & \multirow{2}{*}{$\begin{array}{l}\text { Foreign ones } \\
\text { different } \\
\text { subjects }\end{array}$} & \multirow{2}{*}{$\begin{array}{l}\text { Foreign ones } \\
\text { library } \\
\text { subjects }\end{array}$} & \multirow{2}{*}{$\begin{array}{l}\text { Russian ones } \\
\text { library } \\
\text { subjects }\end{array}$} & & & & \\
\hline & & & & Readers & Agency & Library & Authors \\
\hline $\begin{array}{l}\text { General information: subject, address, } \\
\text { editorial board }\end{array}$ & 20 & 17 & 9 & - & + & + & + \\
\hline Publishing house information & 20 & 11 & 9 & - & + & + & + \\
\hline Archives: content & 20 & 20 & 9 & + & - & + & \\
\hline $\begin{array}{l}\text { Information for authors and reviewers: } \\
\text { instruction }\end{array}$ & 20 & 19 & 9 & - & - & - & + \\
\hline Article submission system & 20 & 19 & 0 & - & - & - & + \\
\hline Subscription & 18 & 16 & 9 & + & + & + & \\
\hline The full text (in different access modes) & 2 & 1 & 4 & + & - & + & - \\
\hline Open access articles & 1 & 2 & & + & - & + & - \\
\hline Abstracts to articles & 2 & & 4 & + & - & - & + \\
\hline Announcement, current issue & 19 & 20 & 9 & + & - & - & + \\
\hline Most cited and downloaded articles & 10 & 12 & - & + & - & - & + \\
\hline Viewing online version ahead of print & 6 & 3 & - & + & - & - & + \\
\hline $\begin{array}{l}\text { Different tools to work with articles: } \\
\text { - save to my profile } \\
\text { - get the link to this article by e-mail } \\
\text { - export citation to a variety of pro- } \\
\text { grams for managing bibliographic } \\
\text { information citation alerts } \\
\text { - request permissions (to use the } \\
\text { article in materials, in books, } \\
\text { journals and so on) } \\
\text { - share in social networks }\end{array}$ & 6 & 2 & - & + & - & - & + \\
\hline Multimedia & 4 & 2 & - & + & - & + & + \\
\hline $\begin{array}{l}\text { Additional information: } \\
\text { - best publiser's journals } \\
\text { - patient pages } \\
\text { - journal covers } \\
\text { - methodical recommendations } \\
\text { - vacancy }\end{array}$ & 12 & 5 & 2 & + & - & - & + \\
\hline RSS and e-mail subscription & 11 & 11 & 1 & + & - & - & + \\
\hline $\begin{array}{l}\text { Special sections: } \\
\text { - for librarians } \\
\text { - for readers } \\
\text { - for advertisers }\end{array}$ & 7 & 10 & - & + & + & + & + \\
\hline Social network tools & 19 & 17 & 2 & + & - & - & + \\
\hline $\begin{array}{l}\text { Recommendation service: } \\
\text { - for friend } \\
\text { - for librarian }\end{array}$ & 9 & 6 & - & + & - & + & - \\
\hline
\end{tabular}


L. B. Shevchenko, 2016, no 4, pp. 19-23

Table (concluded)

\begin{tabular}{|c|c|c|c|c|c|c|c|}
\hline \multirow{3}{*}{ Information } & \multicolumn{3}{|c|}{ Available on journal websites: (number of sites) } & \multirow{2}{*}{\multicolumn{4}{|c|}{$\begin{array}{c}\text { Intended for: } \\
(+- \text { intended, }-- \text { not intended })\end{array}$}} \\
\hline & \multirow{2}{*}{$\begin{array}{l}\text { Foreign ones } \\
\text { different } \\
\text { subjects }\end{array}$} & \multirow{2}{*}{$\begin{array}{l}\text { Foreign ones } \\
\text { library } \\
\text { subjects }\end{array}$} & \multirow{2}{*}{$\begin{array}{l}\text { Russian ones } \\
\text { library } \\
\text { subjects }\end{array}$} & & & & \\
\hline & & & & Readers & Agency & Library & Authors \\
\hline $\begin{array}{l}\text { Abstracting/indexing (information } \\
\text { system list where journal articles are } \\
\text { abstracted and indexed) }\end{array}$ & 3 & 9 & - & + & - & + & + \\
\hline My account/profile & 19 & 14 & - & + & - & - & + \\
\hline Open access & 8 & 10 & - & + & - & - & + \\
\hline $\begin{array}{l}\text { Metrics: SNIP, SJR, Impact factor, } \\
\text { 5-Year Impact Factor }\end{array}$ & 2 & 3 & - & - & + & - & + \\
\hline
\end{tabular}

websites contain the following data: general information about journal (subject, addresses, editorial board); information about publishing organization; content of issues, announcement of current issue, subscription. Instructions for authors are often placed in a special section for them, which contains recommendations, and rules for an article reviewing and submission. Unfortunately, submission systems are not used on the websites of Russian library journals, only online «Bulletin of Kazan State Institute of Culture and Art» and «Bibliosphere» are working on their implementation, although almost all foreign journals have such system.

One can view the most cited and downloaded articles at websites of foreign journals, meanwhile domestic library journals have no such possibility. Also, many foreign journals provide users with a variety of tools to work with articles, such as receiving a reference to the article by e-mail, transfer citing articles to a variety of programs for bibliographic information management, getting a citation alert, getting permission to share the content (to use this article for curriculum materials, books, journals, etc.).

Almost half of the foreign journals present on their websites special sections for librarians, readers, advertisers, containing a variety of resources and services for these groups of users. E.g., for librarians: statistics, subscription, ordering information, a license agreement, the possibility of downloading cataloging records, price lists; for readers: publication ethics, to recommend the journal to the library, subscription notification.

Also websites of foreign journals have advice services: to recommend to a friend, a librarian, etc.

22 of 40 viewed foreign journals have RSS feeds and e-mail notification. RSS-feeds provide continuous notification of the latest news or articles, but unilaterally [4].

«Quarterly Journal of Economics» offers a system of notification services, comprising:

- delivery of content via e-mail,

- submitted for publication by e-mail,

- CiteTrack notification (allows you to track topics and authors publishing in journals),
- RSS Feed,

- alert thematic collections.

Only 1 domestic journal «Bibliosphere» offers RSS and e-mail alerts services.

Almost all foreign scientific journals (37 of 40 viewed ones) provide links to social networks such as YouTube, Twitter, Facebook or blogs on their websites.

Existing social networks perform different functions. They inform about new articles, serve as forums and contribute to the professional knowledge dissemination. Social networks complement the information content created by the journal. They can act as information filters, informing about new articles and contributions from readers: «like», recommendations, comments, tweets or add a link to an article. The social networks of scientific communication add to the functions of scientific journals. They reflect readers' opinions, and allow editors to publish relevant information in other formats, and not only in the format of a scientific article [2, 5]. Only 2 of 9 viewed websites of domestic target journals present social networks.

Some of the journals (6 of 40) offer multimedia materials on their websites. For example, «Annual Review of Immunology» journal publishes on its website SUPPLEMENTAL MATERIALS, i.e. materials that are not published in a printed version of the journal (video, graphics, tables, 3D-animation). «Journal of Academic Librarianship» web site has posted: AudioSlides a short, 5-minute presentation, in which the author presents his article, and Interactive Plot Viewer - data and other quantitative results represented in the article (figures and tables). The article printed version gives a link to additional materials on the journal website. Video and audio information, in which scientists explain the essence of their work, help to make research reports easier to understand [10].

Almost all foreign journals provide the service «My Account» on their websites. If registered, users gain additional services: e-mail alerts for new content and saved searches; preservation of publications and searches in their profile; opportunity to purchase individual articles; 
alerts and promotional offers on recommended publications, based on a user's profile, etc.

Foreign journals indicate journal metrics on their websites: Source-Normalized Impact per Paper (SNIP), SJR, Impact factor, 5-Year Impact Factor. Article Metrics allow the researcher to get operative information about the paper significance (based on citation) and the scientific community interest to the article. This helps to decide whether to read the full text or not.

It will be useful for authors to get data about abstracting/indexing of the journal in a list of information systems, which review and index journal articles. Almost one-third of viewed foreign journals post such information.

Nearly a half of investigated foreign journals are involved in the Open Access System - Open access journals. Advantage of Open Access is the rate of scientific information exchange and the accessibility of the information to validate its scientific status. And as some researchers have noted the attention of readers to the articles of journals in Open Access is longer than that one in the paid access $[1,7]$.

The Open Access model is implemented by different approaches: some journals provide full access to all readers, some suggest the authors to pay for the ability to publish their articles in open access mode, some conclude agreements with authors implying share copyright and allowing free circulation of information in an article, and so on [13]. The use of this model in Russia is lagging behind other countries, as mechanisms of Open Access are still little used.

The editorial board of «Bibliosphere» seeks to explore and learn advanced foreign experience, therefore makes steps towards the development of open access to the journal publications. On the journal website full-text articles are available from the beginning of journal issue (2005) until 2014. Since 2017 all the publications of the journal will be in open access.

On the websites of foreign scientific journals the additional services are offered, such as: Internet-shop services to authors - the translation of the manuscript, the English text peer review, image preparation («Cell») journal, e.g.). «Foundations and Trends in Machine Learning» offers to download LaTeX style files for the journal (LaTeX - desktop publishing software, computer typesetting system).

The analysis also has shown that the journal websites are oriented to all groups of interest. The following sections are intended for authors: general information about the journal and publishing organization, sections for authors, most cited and downloaded articles, ability to view an article online version before sending to a publisher, a variety of tools to work with articles and multimedia materials, additional information on target journals, journal metrics, abstracting/indexing, personal accounts. Readers will also be interested in the above listed sections, as well as subscription, announcements of releases and abstracts, full texts, newsletter, advice services, social networks tools. The information about a journal - its metrics, specially allocated areas - will be useful for agencies, publishing organization subscribers, partners, publications conditions; general information about the journal and the publishing organization, subscription services recommendations, information on the journal abstracting and indexing - for libraries.

The above mentioned data allow receiving information about journals publication and distribution, new publications, promptly communicate with publishers and editorial boards, and considerable part of information is intended for readers and authors. All these show that this type of communication is necessary, dynamically developing and improving.

Thus, one can conclude that the scientific journals sites are constantly being developed, providing all interested groups of users new resources and services, as in terms of the communicative approach, and are an important element in online environment of scientific communication. Websites of domestic library journals unfortunately lag behind foreign ones. The results of research will be used for further development of «Bibliosphere» website.

\section{References}

1. Davis P. M., Walters W. H. The impact of free access to the scientific literature: a review of recent research. Journal of Medical Library Association, 2011, 99 (3), 208-217.

2. Eysenbach G. Can Tweets predict citations? Metrics of social impact based on Twitter and correlation with traditional metrics of scientific impact. Journal of Medical Internet Research, 2011, 13 (4). URL: http://www.jmir.org/2011/4/ e123/ (accessed: 10.08.2016).

3. Ferreira A. G. C., Caregnato S. E. Visibility of scientific journals: a study based on the website of scientific journals at Universidade Federal do Rio Grande do Sul. Transinformação, 2014, 26 (2). URL: http://www.scielo.br/scielo.php? script=sci_arttext\&pid=S0103-37862014000200177\&lng= pt\&nrm=iso\&tlng=en\#aff1 (accessed 29.08.2016).

4. Giustini D. How Web 2.0 is changing medicine. British Medical Journal, 2006, 333, 1283-1284.

5. Kortelainen T., Katvala M. «Everything is plentiful - except attention». Attention data of scientific journals on social web tools. Journal of Informetrics, 2012, 6, 661-668.

6. Maina S. Webometrics and journal websites. European Sci. $E d ., 2012,38$ (3), 65-66.

7. Wang X., Mao W., Xu Sh., Zhang Ch. Usage history of scientific literature: Nature metrics and metrics of Nature publications. Scientometrics, 2014, 98 (3), 1923-1933.

8. Weideman M. Comparative analysis of homepage Website visibility and academic rankings for UK universities. Information Research, 2013, 18 (4), 599.

9. Abramov E. G. Scientific journal website creation in Russia. Nauchnaya periodika: problemy i resheniya, 2011, 3, 22-26. (In Russ.).

10. Bogdanova I. F. On-line space of scientific communications. Sotsiologiya nauki i tehnologii, 2010, 1 (1), 140-161. (In Russ.).

11. Lavrik O. L., Glukhov, V. A., Elepov B. S. The scientific communication system development: journals of SB RAS. Nauchnye i tekhnicheskie biblioteki. Ser. 1, 2002, 8, 18-24. (In Russ.).

12. Shevchenko L. B. A website of scientific journals publishing office as an element of the scientific communication system. Elektronnye resursy bibliotek regiona : materialy 


\section{B. Shevchenko, 2016, no 4, pp. 19-23}

region. nauch.-prakt. konf. (Novosibirsk, 24-28 sent. 2007 g.). Novosibirsk, 2008, 225-229. (In Russ.).

13. Emmett L. A., Grinberg M. L., Piterson E. T. Problems of the Open Access model and authors payments for publica- tion: providing access of readers and authors in the world community frames. Nauchnaya periodika: problemy i resheniya. 2013, 3 (5), 8-18. (In Russ.). DOI: 10.18334/np 35101.

Recieved on Sept. 16, 2016

About the author: Lyudmila B. Shevchenko - candidate of pedagogical sciences, senior researcher of the Laboratory of information-systematic analysis, SPSTL SB RAS 